\title{
The Development of Interactive Multimedia Based on the Quiz Education Game on the Content of IPS Learning in Basic Schools
}

\author{
Tresna Aditya; Ajat Sudrajat; M. Syarif Sumantri \\ Universitas Negeri Jakarta, Indonesia \\ http://dx.doi.org/10.18415/ijmmu.v8i4.2627
}

\begin{abstract}
This study aims to develop interactive multimedia based on the Game Quiz Education as a form of interactive learning media, and is able to support the learning process in an effort to improve student learning outcomes. The method used is research and development with the Dick and Carey Model. This research was conducted on fifth grade students at the Margahayu XXIII State Elementary School, Bekasi City, Indonesia. The sampling technique used was purposive sampling. Data collection techniques used were tests, interviews, questionnaires, and documents. The results of this research can be concluded that interactive media based on game quiz education in social science learning is developed effectively because it uses multimedia assistance as a teacher's aid in delivering social science learning material.
\end{abstract}

Keywords: Interactive Multimedia; Game Quiz Education; Elementary School

\section{Introduction}

In its current development, science and technology (IPTEK) is developing rapidly and spreading widely so that it affects all areas of life, including in the field of education. Computers as a technology development have shifted their use as a learning resource (B Setiawan et al., 2017). In learning activities, the use of computers is used to apply the concept of effectiveness, to help humans do certain tasks well, quickly, precisely and pleasantly. This technology can be used to solve various problems. If it is in the learning process, it will be more effective and efficient if it is supported by the use of adequate media. Because students interact directly with learning resources that can lead to the achievement of optimal learning outcomes (Yetti et al., 2021). According to Sadiman (2009) media is defined as everything that is used to transmit a message from the sender to the recipient (students) so that it can stimulate thoughts, feelings, attention and interest and attention so that the learning process occurs. If simplified, the media is used to facilitate student learning in order to understand the material presented. Other reasons for using media include simplifying messages, reducing verbalism, equalizing perceptions, attracting attention, and saving time (Sari et al., 2020).

According to Oetomo's opinion (2007) shows that: "Without using the media, the teaching and learning process cannot develop properly. Moreover, if we want to create an interactive presentation 
pattern, then those media will be the right tools for students to use. " Not only one learning medium is used, by using a computer it is formed a collection of several media called multimedia. The explanation of multimedia is a combination or combination of text, photos, graphic art, sound, animation, and video elements that have been digitally manipulated (Vaughan, 2011).

The development of communication and information technology not only makes learning easy, here as a teacher (teacher) is also required to be able to master current technology which is growing rapidly. Where now the teacher acts as a facilitator and students who are active in learning, not only that teachers are also expected to be able to develop media that can be used to support effective and fun learning according to the objectives set according to Hamalik, quoted by Kustandi \& Sutjipto (2011). ), "For that the teacher / teacher must have sufficient knowledge and understanding of learning media, which includes the following: (a) Media as a means of communication in order to make the teaching and learning process more effective; (b) The function of the media in order to achieve educational goals; (c) the ins and outs of the learning process; (d) The relationship between teaching methods and learning media; (e) Value or benefits of educational methods in learning; (f) Selection and use of educational media; g) Various types of educational media tools and techniques; (h) Educational media in every subject; i) Motivational efforts in educational media ".

In the 2013 curriculum, especially for the elementary level, there were several changes in the subject of Social Sciences (IPS) (Rachamatika et al., 2021; Sudrajat et al., 2021). Social studies subjects in grades I to III were eliminated, but social studies content remained and was integrated into Indonesian, PPKn and Mathematics subjects. While Grades IV to VI social studies subjects stand on their own, but the learning is given thematically integrated with other subjects. Geography, history, economy and sociology are integrated into themes in an integrated manner (Asrifah et al., 2020).

Through integrated thematic learning, social science learning is expected to be more meaningful for students. Social Science subjects are formulated on the basis of social reality which is organized with an interdisciplinary, multidisciplinary and transdisciplinary approach (Bramianto Setiawan, 2015). Social studies learning is carried out in order to achieve competence in spiritual attitudes, social attitudes, knowledge, and skills (Pramujiono et al., 2020). Although KD in spiritual attitudes and social attitudes is not formulated as separate KDs, spiritual attitudes and social attitudes are developed through indirect learning activities (Indirect Teaching).

SD IPS learning is carried out to make students active, critical, civilized, and aware as citizens who can play a role in the life of multicultural communities in the local, national, and global environment. The scope of IPS material in elementary schools, begins with an introduction to the environment and the closest community, starting from the district, provincial, national and international levels. Between one region and another have a connection. The international environment in the SD environment is limited to the introduction of the ASEAN environment. Development of Social Studies Subjects for SD in an integrated thematic manner, not only transferring cognition, but also building simple social attitudes and skills, such as being able to observe and communicate the characteristics and connectivity of the environment and the closest community to other parties politely through cooperation with using technology (Iskandar, 2019).

This research begins by carrying out preliminary field observations as a needs analysis to analyze the need for a field development model in the use of instructional media (Bramianto Setiawan \& Iasha, 2020). Needs analysis was carried out by distributing questionnaires to teachers and students in elementary schools. From the results of the needs analysis, it was found that the use of instructional media was very helpful and made it easier for students to learn, but the teacher still had difficulty determining and choosing the right media according to the material and needs of students. Observing from the results of the needs analysis in the use of instructional media for teachers, another factor of concern to 
researchers was that the results of the analysis of the students' needs identified that social studies learning was a difficult and boring subject because the material provided was only by explaining what was in the book. The media usually used by the teacher is limited to the pictures in the textbook. However, the use of pictures has not been able to generate maximum interest and motivation of students. Presentation of material in textbooks as the main learning resource in learning is still less attractive to students. This is in line with Cholisin's opinion, which explains that the tradition of social studies learning as social science learning today, especially in Indonesia, has a tendency to face problems of lower quality, which is caused by not paying attention to the development of social science theories and methodologies such as the patterns of thinking of social scientists (Setiawan, 2013).

From the observations of facilities and infrastructure, in schools, computer facilities and interactive CDs are available in good condition, but they are underutilized and integrated with learning due to the lack of teacher ability to operate them (Bramianto Setiawan et al., 2020). Interactive CDs are also deemed less attractive and difficult to understand and used by teachers. Through observations and research, experts have further strengthened the conclusion that in terms of the results or impact of social studies education on social life, it is still not very visible, the manifestation of social values developed at school has not been seen in everyday life, social skills are still of concern, participation in community activities is also is getting smaller. In the implementation of learning, social studies tends to emphasize the knowledge aspect and is too centered on the teacher who directs material in the form of information that does not develop value thinking but only forms a culture of memorization and not critical thinking.

The learning process, especially social studies learning in elementary school, takes precedence over the results obtained. Student centered learning tends to show more of the current educational paradigm. This is one thing why learning media is needed in the learning process. In the world of education, the development of technology and information has had a positive impact. With the development of information technology, the world of education is getting better, it is marked by innovations in the use of learning media in the world of education. The use of appropriate learning media can provide benefits for students. The interest in understanding a material using learning media can help students to master the material. Based on research conducted by Pramono \& Wiyanto (2014), it is explained that, in general, learning media can be concluded as a learning tool that helps teachers convey material content to students so that it can improve the quality of the learning process. According to Sudjana \& Rivai (2010), the position of teaching media is in the teaching method component as an effort to enhance the process of teacher-student interaction and student interaction with their learning environment. Through the use of instructional media it is expected to enhance the quality of the teaching and learning process which in turn can affect the quality of student learning outcomes. Several types of media commonly used in educational and teaching activities can be classified into graphic media, photographic media, three-dimensional media, projection media, audio media and the environment as teaching media.

In relation to learning in elementary schools, there are many learning media that can be used. However, in this study the researcher wanted to develop interactive multimedia based on the Quiz Education Game on the Social Studies learning content of grade V students in elementary schools. The development of learning media using computers, especially interactive learning multimedia to realize effective and efficient learning in order to achieve predetermined learning objectives. The use of media in carrying out the learning process should be in accordance with the material being taught because media is one of the factors that support the success of a learning process. Educational games are one type of game that is not only entertaining but contains knowledge that is conveyed to its users Huizenga, (Admiraal, Dam, \& Voogt, 2019; Huizenga, Dam, Voogt \& Admiraal, 2017). Educational games can be used as an educational medium that can be used as a medium of learning. This type of game is commonly used to invite users to learn while playing. Through this learning process, users can gain knowledge (Lameras, Arnab, Dunwell, Stewart, Clarke \& Petridis, 2017), so that educational games are a new breakthrough 
used in the world of education. Therefore, the authors need to develop interactive multimedia based on the Game Quiz Education as a form of interactive, alternative learning media capable of supporting the learning process in an effort to improve student learning outcomes.

\section{Method}

This study uses the method of research and development (Research and Development). According to Brog and Gall, the method of research and development is "process used to develop and validate educational products." It means a process used to develop and validate research products. In this research method focuses on developing interactive multimedia based on game quiz education which will be made according to the needs of fifth grade students of Margahayu XXIII Elementary School, Bekasi City in Indonesia. This model consists of ten planning stages in developing interactive multimedia based on this education quiz game. The ten stages include: (1) Analysis of learning needs and objectives, (2) Conducting learning analysis, (3) Identifying input behavior and student characteristics, (4) Formulating indicators, (5) Developing standard reference test items, (6) Developing learning strategies, (7) Developing and selecting learning materials, (8) Designing and implementing formative evaluations, (9) Revising learning materials, (10) Designing and implementing summative evaluations. The data analysis technique used is descriptive qualitative statistics. Qualitative descriptive statistics are used to analyze data by describing or describing the collected data as it is. Data collection techniques are divided into two types, namely test and non-test. Non-test data collection techniques in the form of interviews and observations.

\section{Results}

\section{Needs Analysis}

At this stage the researcher has conducted an analysis of the potential and existing problems, this stage is carried out in elementary schools by observing the needs of students in the learning process of social education. In the social education learning process, it is still centered on the Teacher Oriented method, which is a teacher-centered learning process. However, the teacher has not used interactive learning media, the media used is still conventional. In this case, students are less enthusiastic and feel bored with the ongoing learning process. Meanwhile, we now live where all rely on technological sophistication. technological advances also have a positive influence, especially in the field of education to improve the quality of interesting learning, and be able to develop students' abilities to the fullest. There are adequate learning facilities and infrastructure, this has the potential to take advantage of existing facilities, students need attractive learning media to support a more effective learning process. Based on the observations that have been passed, it can be concluded that interactive multimedia based on the Game Quiz Education as a form of interactive, alternative learning media is able to support the learning process in an effort to improve student learning outcomes in social science learning in elementary schools.

\section{Evaluation}

At this evaluation stage there are several ways to evaluate the results of the validation test and the results of the evaluation of field trials consisting of small group tests and large group tests, while the results of the evaluation are as follows: 
Table 1. The Results of the Evaluation of the Interactive Multimedia Expert validation

\begin{tabular}{lcc}
\hline Aspect & Farming Items & Average \\
\hline Multimedia Display & 17 & 5.68 \\
Multimedia Application Programming & 7 & 5.12
\end{tabular}

The results of the validation assessment by interactive multimedia experts on the interactive multimedia display aspect obtained an average value of 5.68 with the criteria "Very Good". For the programmer aspect of interactive multimedia applications the average score is 5.12 with the criteria "Very Good". It can be said that the Multimedia-Based Education quiz game in social science learning deserves to be a learning medium by the assessment of interactive multimedia experts. Furthermore, the results of material expert validation can be seen from the table below:

Table 2. The results of the Material Expert Validation Assessment

\begin{tabular}{lcl}
\hline Aspect & Farming Items & Average \\
\hline Eligibility of material content & 5 & 4.43 \\
Feasibility of Material Presentation & 5 & 4.77 \\
\hline
\end{tabular}

The results of the material expert evaluation validation show that the content feasibility aspect obtains an average value of 4.43 with the criteria "Very Good". For the feasibility aspect of the presentation of the material obtained an average value of 4.75 with the criteria "Very Good". After the media was validated by material experts and media experts, then a Small Group Trial was carried out involving 30 grade $\mathrm{V}$ elementary school students. The results of the small group trial can be seen in the table below:

Table 3. Feasibility Trial in Small Groups

\begin{tabular}{llll}
\hline & Aspect & $\mathrm{N}$ & Average \\
\hline Ease of Use & & 30 & 5.40 \\
Display & 30 & 5.55 \\
Quality of contents & 30 & 5.60 \\
\hline \multicolumn{2}{l}{ Total } & 5.51 \\
\hline
\end{tabular}

Based on the results of the small group test, the average value for the Ease of Use aspect was 5.40 with the criteria "Good". On the display aspect, it has an average value of 5.55 with the criteria "Good". In the aspect of Quality of contents, it has an average value of 5.60 with the criteria "Very Good". So that the final value of the feasibility of interactive learning media is 5.51, it can be said that the development of a game-based multimedia education quiz to improve social science learning outcomes in elementary schools is feasible to use from the results of small group trials.

The final trial after going through the stages of expert validation and small group trials and improvement trials, then a field trial was carried out on 100 students, the results of this trial are presented in the table below: 
Table 4. Field Trial (large group)

\begin{tabular}{lll}
\hline Aspect & $\mathrm{N}$ & Average \\
\hline Ease of Use & 70 & 4.77 \\
Display & 70 & 4.81 \\
Quality of Content & 70 & 3.81 \\
\hline Total & & 4.46 \\
\hline
\end{tabular}

In the Field Trial stage, student response data to the development of interactive multimedia based on a scientific approach can be seen from three aspects of assessment, namely the ease of use aspect which has an average value of 4.77 with the criteria "Very good." 81 with the criteria "Very Good." Aspects of the quality of the content of the material obtained an average value of 3.81 with the criteria "Very Good." The average total field trials obtained were 4.30 it can be said that the development of Game Quiz-Based Multimedia Education to improve learning outcomes is appropriate for use in social science learning in elementary schools.

\section{Discussion}

Based on the results of research that has been suggested that in the development of Game-Based Multimedia Education Quiz in improving social science learning outcomes it is found that these products have valid values and can be used in learning. Multimedia in general is a combination of three elements, namely sound, images and text. Or Multimedia is a combination of at least two input or output media of data, media can be audio (sound, music), animation, video, text, graphics and images. This is in line with research conducted by Rachmadtullah, Zulela \& Sumantri, (2018) which states that the use of multimedia in learning can make it easier for teachers to convey messages.

In general, the benefits that can be obtained by using the learning process are more interesting, more interactive, the quality of student learning can be improved and the teaching and learning process can be carried out anywhere and anytime. The advantage of multimedia in interactive is that this media is inherently able to force users to interact with material both physically and mentally (Huang, Zhang, Zhu, Zhang \& Meng, 2019; Wang, Li, Mayer \& Liu, 2018). Of course this ability to force depends on how effective the instructional instruction is able to attract users to actively try out the learning presented. By using multimedia learning, users will be invited to immediately try and use Microsoft which is available but different if the same material is presented with books or videos.

\section{Conclusion}

Based on the findings and discussion that have been described, the conclusion in this study is that the application of interactive multimedia based on the Game Quiz Education in social education learning is valid and efficient so that it can be used as learning material in elementary schools. Interactive multimedia that is able to present material attractively, and able to accommodate each student's learning style. With its advantages, interactive multimedia can be used as an alternative media for learning in accordance with the characteristics of students in learning materials including social education material. 


\section{References}

Asrifah, S., Solihatin, E., Arif, A., Rusmono, \& Iasha, V. (2020). Pengaruh Model Pembelajaran Problem Based Learning Terhadap Hasil Belajar Pendidikan Pancasila Dan Kewarganegaraan Siswa Kelas V SDN Pondok Pinang 05. Buana Pendidikan: Jurnal Fakultas Keguruan Dan Ilmu Pendidikan, 16(30 SE-), 183-193. https://doi.org/10.36456/bp.vol16.no30.a2719

Lameras, P., Arnab, S., Dunwell, I., Stewart, C., Clarke, S., \& Petridis, P. (2017). Essential features of serious games design in higher education: Linking learning attributes to game mechanics. British journal of educational technology, 48(4), 972-994. https://doi.org/10.1111/bjet.12467

Huizenga, J. C., Ten Dam, G. T. M., Voogt, J. M., \& Admiraal, W. F. (2017). Teacher perceptions of the value of game-based learning in secondary education. Computers \& Education, 110, 105-115. https://doi.org/10.1016/j.compedu.2017.03.008

Huizenga, J., Admiraal, W., ten Dam, G., \& Voogt, J. (2019). Mobile game-based learning in secondary education: Students' immersion, game activities, team performance and learning outcomes. Computers in Human Behavior, 99, 137-143. https://doi.org/10.1016/j.chb.2019.05.020

Iskandar, R. (2019). Pengembangan Media Pembelajaran IPS Berbasis Komik di Sekolah Dasar. Jurnal Ilmiah Pendidikan Guru Sekolah Dasar, 3(2), 237-246.

Kustandi, C., \& Sutjipto, B. (2011). Media pembelajaran manual dan digital. Bogor: Ghalia Indonesia.

Oetomo, B. S. D. (2007). Pengantar Teknologi Informasi Internet.Litbang Kemenkes

Pramono, R., \& Wiyanto, T. (2014). Penerapan Media Pembelajaran Berbasis Untuk Meningkatkan Hasil Belajar Siswa Mata Pelajaran Alat Penerapan Media Pembelajaran Berbasis Macromedia Flash 8 Untuk Meningkatkan Hasil Belajar Siswa Mata Pelajaran Alat Ukur Macromedia Flash 8 Untuk Menin. Jurnal Pendidikan Teknik Mesin, 2(02), 114-120.

Pramujiono, A., Suhari, S. H., Rachmadtullah, R., Indrayanti, T., \& Setiawan, B. (2020). KESANTUNAN BERBAHASA, PENDIDIKAN KARATER, DAN PEMBELAJARAN YANG HUMANIS. Indocamp.

Rachamatika, T., M. Syarif Sumantri, Agung Purwanto, Jatu Wahyu Wicaksono, Alrahmat Arif, \& Vina Iasha. (2021). Pengaruh Model Pembelajaran Dan Kemandirian Belajar Terhadap Kemampuan Berpikir Kritis IPA Siswa Kelas V SDN Di Jakarta Timur. Buana Pendidikan: Jurnal Fakultas Keguruan Dan Ilmu Pendidikan, 17(1 SE-), 59-69. https://doi.org/10.36456/bp.vol17.no1.a3162

Sadiman, A. S. (2009). Media Pendidikan pengertian, pengembangan dan pemanfaatannya. Litbang Kemenkes

Sari, Y., Luvita, R. D., Cahyaningtyas, A. P., Iasha, V., \& Setiawan, B. (2020). Pengaruh Metode Pembelajaran Struktural Analitik Sitentik terhadap Kemampuan Menulis Permulaan di Sekolah Dasar. Jurnal Basicedu, 4(4), 1125-1133.

Setiawan, B, Septianto, R., Suhendra, D., \& Iskandar, F. (2017). Measurement of 3-axis magnetic fields induced by current wires using a smartphone in magnetostatics experiments. Physics Education, 52(6), 065011. https://doi.org/10.1088/1361-6552/aa83e3

Setiawan, Bramianto. (2015). Eksperimentasi Model Pembelajaran Problem Solving dengan Pendekatan Peer Tutoring Berbasis Metode Pembelajaran Eksperimen dan Demonstrasi pada Materi Fluida Statis Siswa Kelas X MIA SMA Negeri 1 Banyudono.

Setiawan, Bramianto, \& Iasha, V. (2020). Corona Virus Disease 2019: The Perspective Opinion From Pre-Service Elementary Education Teacher. Education, Sustainability \& Society, 3(2), 33-36. https://doi.org/10.26480/ess.02.2020.33.36

Setiawan, Bramianto, Juniarso, T., Fanani, A., \& Iasha, V. (2020). Pembelajaran Online Di Masa Pandemi Covid-19: Pengaruhnya Terhadap Pemahanan Konsep Fisika Mahasiswa. Jurnal Pendidikan Dasar, 11(02), 230-236.

Setiawan, D. (2013). Reorientasi Tujuan Utama Pendidikan Ilmu Pengetahuan Sosial Dalam Perspektif Global. JUPIIS: Jurnal Pendidikan Ilmu-Ilmu Sosial, 5(2).

Sudjana, N., \& Rivai, A. (2010). Media pembelajaran. Bandung: Sinar Baru Algensindo. 
Sudrajat, A., Meiliana Lovienica, \& Vina Iasha. (2021). Pengaruh Model Resource Based Learning Terhadap Hasil Belajar Ilmu Pengetahuan Sosial (IPS) Siswa Kelas IV SD Sekolah Dasar. Buana Pendidikan: Jurnal Fakultas Keguruan Dan Ilmu Pendidikan, 17(1 SE-), 70-75. https://doi.org/10.36456/bp.vol17.no1.a3217

Vaughan,T. (2011). Multimedia Making it work ;8th Edition. New York: McGraw-Hill

Wang, F., Li, W., Mayer, R. E., \& Liu, H. (2018). Animated pedagogical agents as aids in multimedia learning: Effects on eye-fixations during learning and learning outcomes. Journal of Educational Psychology, 110(2), 250.

Yetti, E., Yufiarti, Pramitasari, M., Suharti, Iasha, V., \& Setiawan, B. (2021). The Influence of Dance Instructional Strategy and Teacher's Pedagogy Competence on Classroom Climate. Elementary Education Online, 20(1), 642-650. https://doi.org/10.17051/ilkonline.2021.01.54

\section{Copyrights}

Copyright for this article is retained by the author(s), with first publication rights granted to the journal.

This is an open-access article distributed under the terms and conditions of the Creative Commons Attribution license (http://creativecommons.org/licenses/by/4.0/). 